Article

\title{
Grain-Size Distribution and Structural Characteristics of Varved Sediments from Lake Żabińskie (Northeastern Poland)
}

\author{
Maurycy Żarczyński ${ }^{1, * \mathbb{D}}$, Jacek Szmańda ${ }^{2} \mathbb{D}$ and Wojciech Tylmann ${ }^{1}$ (D) \\ 1 Faculty of Oceanography and Geography, University of Gdansk, 80-309 Gdansk, Poland; \\ wojciech.tylmann@ug.edu.pl \\ 2 Faculty of Geography and Biology, Pedagogical University of Cracow, 30-084 Krakow, Poland; \\ jszmanda@up.krakow.pl \\ * Correspondence: maurycy.zarczynski@phdstud.ug.edu.pl
}

Received: 29 November 2018; Accepted: 2 February 2019; Published: 4 February 2019

\begin{abstract}
Typically, the description of varve microfacies is based on microscopic sedimentary structures, while standard grain-size analysis is commonly applied with lower resolution. Studies involving a direct comparison of varve microfacies and particle-size distributions, common for clastic environments, are scarce for biogenic varves. In this study, we analyzed nine-year resolution grain-size data from Lake Żabińskie (northeastern Poland) to detect differences between varve microfacies. Six varve microfacies were differentiated using grain-size distributions and sedimentological attributes (calcite layer thickness, dark layer thickness, mass accumulation rate). However, changes in particle-size distributions between different varve types are relatively small and indicate a similar source for the material deposited. Decomposition of grain-size distributions with the end-member approach allows recognition of relative changes for the deposition of allochthonous (mineral) and autochthonous (carbonates, (hydr)oxides) components. Grain-size data suggest that sources of allochthonous material remained constant, while varve formation was controlled mostly by in-lake processes.
\end{abstract}

Keywords: varves; lake sediments; grain-size; end-members

\section{Introduction}

Lacustrine sedimentary records are one of the most important paleoenvironmental archives [1]. Among these, records with varved sediments offer a rare opportunity for annually resolved chronologies and analyses [2,3]. Studies based on varved sediments require careful recognition and confirmation of the annual deposition cycle $[4,5]$. This is mostly achieved with microfacies analysis, which is based on recognition of microscopic sedimentary structures forming the varves $[4,6]$. Careful studies of present-day in-lake processes might further confirm the annual rhythm of sedimentation [4,7]. Most of the paleoenvironmental analyses rely either on geochemical proxies [8], ecological indicators $[9,10]$ or a combination of those [11]. Textural analysis, including particle-size of the accumulated material, provides one of the fundamental characteristics for the study of sedimentary material [12]. Grain-size analyses offer a variety of research opportunities for lacustrine settings. Sediment texture could be used to study material provenance [13], transport [14], and processes such as paleofloods [15,16], monsoons [17], and aeolian activity [18].

Since the inception of the varve chronology method by De Geer [19], grain-size has played an important, diagnostic role, especially in clastic varves [2]. Textural changes in the cold climate are a result of the freeze-thaw cycles affecting allochthonous material supply [20]. This, in turn, leads to the formation of seasonal laminations, reflecting differences in the composition and size of the accumulated 
material [3]. Commonly, the warm season is characterized by larger particles, which originate from the catchment, while their transport is induced by snowmelt and increased runoff. During ice-covered seasons, accumulation of coarse particles decreases leading to dominance of smallest particles. This closes the cycle with a fine-grained layer, often with addition of biogenic material [20-22]. Thus, grain-size plays a fundamental role during the recognition of annual cycles. Thanks to continuous density scans and grey-scale image analyses, grain-size data can be obtained with high, seasonal resolution [23,24]. Therefore, this approach is not only valuable for microfacies analysis but even for semi-automatic varve chronology development.

Contrary to clastic or clastic-biogenic varves, mineral matter plays a minor role with biogenic varves that are dominated by material originating from biochemical processes and lacustrine productivity [2]. This causes a lower interest in particle-size research for this type of varves. Different approaches for sediment pretreatment lead to diverse results, due to different components being possibly removed prior to analysis [25]. The most common procedure is to remove organic matter, carbonates and biogenic silica before measurements $[14,17,20,26]$. However, this leaves possible metal (hydr)oxides intact. This approach could be simplified, for example by removing only organic matter, or further improved with removal of metal (hydr)oxides [25]. Ideally, removal of all non-minerogenic components would effectively lead to the measurement of only allochthonous material of terrestrial origin. However, there is the possibility to destroy clay minerals during subsequent pretreatment steps further influencing the results of measurements. To achieve a full understanding of past processes recorded within biogenic sediments, it might be helpful to measure the size of both allochthonous and autochthonous sediment components.

The aim of this paper is to assess bulk grain-size data as a supporting tool for the discrimination of biogenic varve microfacies. Furthermore, we test the end-member approach for tracing non-detrital sediment components, such as carbonates, metal (hydr)oxides or diatoms. In this study, we used grain-size data from the 2000 year-long, entirely varved sediment core from Lake Żabińskie and compared parameters based on grain-size data with nine-year resolution and previously described varve microfacies.

\section{Materials and Methods}

\subsection{Study Area}

Lake Żabińskie (coring site at $54^{\circ} 07^{\prime} 54^{\prime \prime} \mathrm{N} ; 21^{\circ} 59^{\prime} 01.1^{\prime \prime} \mathrm{E}$ ) is located in the Great Masurian Lakes region (Figure 1A), a part of the Masurian Lakeland (Northeastern Poland) [27]. This postglacial landscape lies within the extent of the Pomeranian Phase of the Vistulian glaciation (ca. 17-16 kBP) [28]. The lake is mostly surrounded by glacial tills, sands, and gravels. Finer material is deposited in depressions and near the lake basins $[29,30]$. Lake Żabińskie is fed by inflows from Lake Purwin and streams from the south passing arable land. The southernmost tributary originates in the Żabinka village bearing considerable amounts of nutrients and mineral matter, with the latter forming a small delta on the southern shore of the lake [31]. Lake Żabińskie drains to the much larger Lake Gołdopiwo located to the west. The lake basin has a simple morphology with one, centrally located deepest point of $44 \mathrm{~m}$ (Figure 1B). Strong seasonal thermal stratification and anoxia in the hypolimnion [4] lead to the formation and preservation of varved lake sediments [31,32]. 


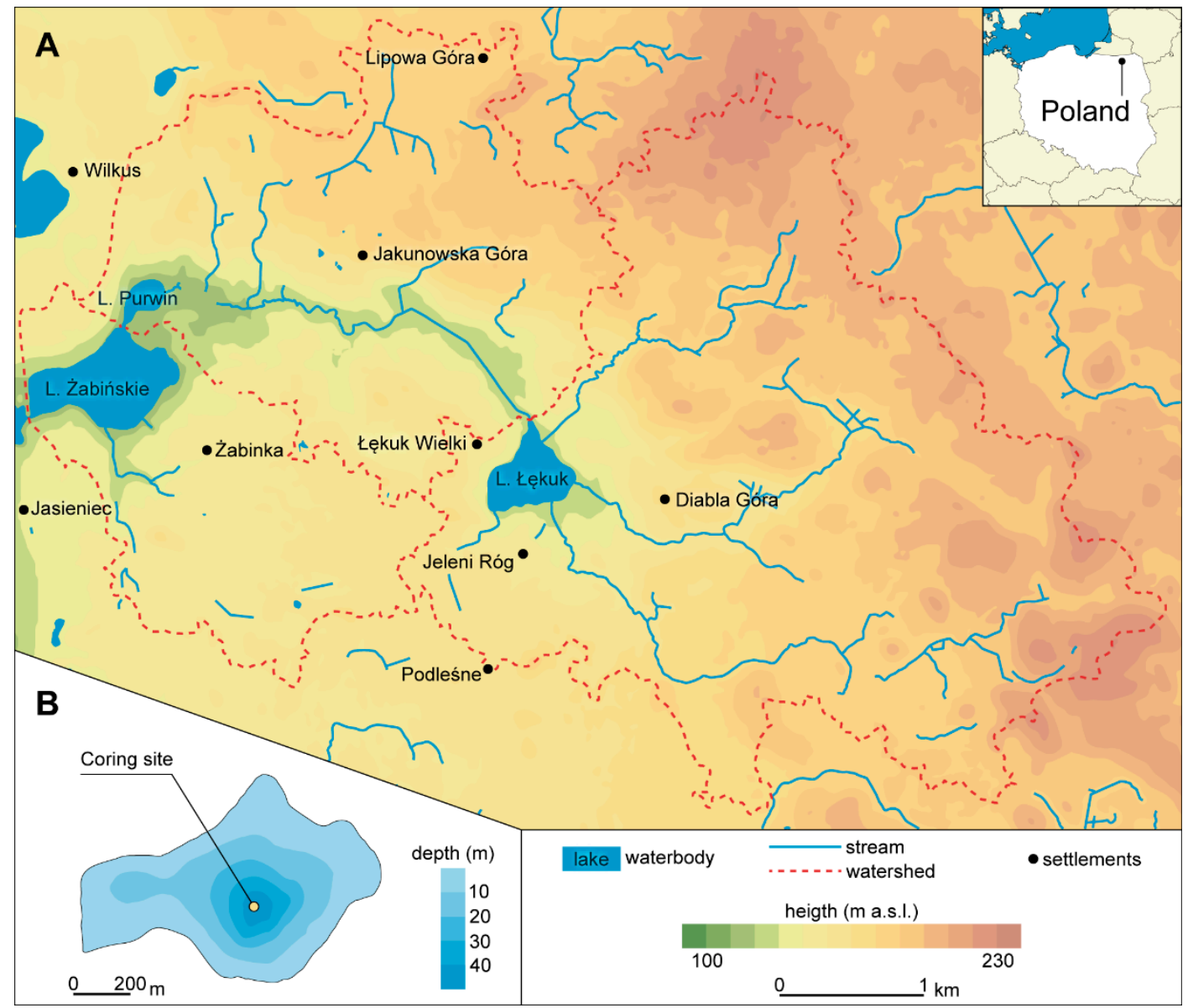

Figure 1. (A) Location of Lake Żabińskie. (B) Bathymetric map with coring site.

\subsection{Coring and Composite Profile}

Coring took place during two field campaigns in the summers of 2011 and 2012. A UWITEC (Mondsee, Austria) coring platform was equipped with a 90-mm diameter piston and gravity corers. The complete sediment profile was $19.5 \mathrm{~m}$ long, while this study focuses only on the previously investigated top $5.95 \mathrm{~m}$ covering the last 2000 years. After retrieval, cores were tightly sealed and stored in a cold room. Later, cores were split into halves, photographed, and macroscopically described. The composite profile was created by correlation of diagnostic horizons.

\subsection{Initial Analyses}

Core half B was continuously subsampled with a temporal resolution of three years per sample, i.e., an average sample thickness of $8.9 \pm 5.2 \mathrm{~mm}( \pm 1 \mathrm{SD})$ with range of 1.6 to $37.0 \mathrm{~mm}$. Dry bulk density was calculated by freeze-drying $1 \mathrm{~cm}^{3}$ of wet sediment and weighing the dry mass.

\subsection{Chronology and Sedimentological Variables}

The chronology is based on three individual varve counts and covers $2028^{+34} /-53$ varve years, reaching year $17^{+34} /{ }_{-53} \mathrm{BCE}$ at a depth of $5.95 \mathrm{~m}$. Additional age control of this period was achieved with 29 AMS ${ }^{14} \mathrm{C}$ dates, ${ }^{137} \mathrm{Cs}$ chronostratigraphic horizons, and the Askja cryptotephra of $1875 \mathrm{CE}$ [33]. Details on the chronology are published by Żarczyński et al. [32]. Based on varve chronology, the mass accumulation rate (MAR in $\mathrm{g} \times \mathrm{cm}^{-2} \times$ year $^{-1}$ ) was calculated by multiplying varve thickness (VT in $\mathrm{mm}$ ) by dry bulk density (DBD in $\mathrm{g} \times \mathrm{cm}^{-3}$ ). Additional measurements of calcite layer thickness (CT in $\mathrm{mm}$ ) and dark layer thickness (DT in $\mathrm{mm}$ ) were done on scanned images of thin sections (2400 DPI), which were previously used for varve counting. In case of multiple calcite layers within one varve, CT 
thickness includes the sum of all individual calcite layers occurring in the given year. DT represents all remaining sublayers, and was calculated by subtracting CT from VT.

\subsection{Microfacies Analysis}

Microfacies analysis was carried out using Axio Imager A2 (ZEISS, Jena, Germany) and L100 (NIKON, Tokyo, Japan) microscopes, with magnifications between $20 \times$ and $500 \times$. Thin sections were investigated using non-polarized and polarized light. A detailed overview of the six main microfacies and their formation processes was published with the varve chronology [32].

\subsection{Grain-Size Determination}

For the determination of particle-size, three parts of equal weight from three consecutive samples were mixed to obtain samples of nine-year resolution. Organic matter was removed by combustion at $550{ }^{\circ} \mathrm{C}$. Carbonates were not removed prior to grain-size measurements. Determination of particle-size distribution was carried out with a Mastersizer 3000 (Malvern, Malvern, United Kingdom) laser particle-size analyzer at the Faculty of Geography and Biology, Pedagogical University of Cracow. Around $50 \mathrm{mg}$ of material were used for each sample to achieve required obscuration of detector. Prior to measurements, ultrasonic disintegration was applied for $60 \mathrm{~s}$. The mean of three measurements for each merged sample was used as the final value.

\subsection{Statistics}

Raw data is provided as a Supplementary Materials (S1). In a first step, annual sedimentological data for each grain-size sample were averaged into mean values. Because grain-size data are attributed to nine-year samples, this led to more than one varve type per sample. Therefore, the percentage share of a given varve type was calculated for each sample. Only samples with one dominant microfacies $(\geq 70 \%)$ were retained for further analyses, excluding $56(26 \%)$ samples from the original dataset of 218 samples. Finally, grain-size data were averaged for each size class to achieve a mean distribution for each varve-microfacies type. Grain-size distribution indices following moment (phi) formulas were calculated with GRADISTAT (version 8.0) [34]. Later, phi values were converted to micrometers. Ternary diagrams were created with ggtern 3.0.0 [35].

Prior to multivariate analyses, variables were log-transformed, scaled and centered with base $\mathrm{R}$ (version 3.5.1) [36]. A principal component analysis (PCA) was carried out to determine the relationship between grain-size indices and sedimentological data. Clustering tendencies and differentiation of varve types were visualized on a PCA biplot. To disentangle genetically different material originating from diverse sedimentary processes [37], grain-size distributions were decomposed with an end-member approach using the EMMAgeo (version 0.9.6) package for R [38].

\section{Results}

\subsection{Microfacies}

Six microfacies were distinguished for the sediments of Lake Żabińskie (Figure 2; [32]). Type I (68 varves) occurred only at the topmost part of the record and is characterized by well-developed calcite lamina followed by diatoms. The rest of the varve is mostly a mixture of minerogenic and organic detritus with the addition of vivianite and pyrite. Characteristic for this microfacies is the occurrence of additional calcite layers throughout the year. Varve type II (165 varves) characterizes the least distinct annual cycle, with a poorly developed calcite/diatom layer marking the beginning of varve years. Diatom frustules and chrysophyte cysts were deposited on top of the calcite layer, with vivianite and pyrite rarely occurring. A fine-grained mineral layer formed sporadically at the end of the year. Type III (1300 varves) is the most abundant of the record, with the simplest pattern of deposition. The beginning of the varve year is marked by a well-developed calcite layer, followed by deposition of mineral and organic detritus. Chrysophytes were more abundant close to the end of the 
varve year. Type IV (85 varves) is very similar to type III, with the addition of the thick diatom layer deposited during the second half of the year. Type V (291 varves) starts with a calcite layer enriched with iron, followed by a mix of calcite grains, diatoms, minerogenic and organic matter. Finally, an iron-rich layer was deposited. This diagnostic layer is at times interrupted by a poorly-developed calcite layer. Type VI (118 varves) is similar to type V, with a distinct (thick) diatom layer occurring prior to deposition of the iron-rich layer. Development and occurrence of different microfacies is strongly connected with land-use changes in the catchment and subsequent changes in the lake mixing regime [39]. Varve types III and IV were deposited mostly during an 1100-year long period (ca. 520 to 1620 CE) of catchment reforestation leading to weaker wind action and meromixis (Figure 3). Types I, II, V, and VI occurred during phases of deforestation leading to intensified lake mixing and better oxygenation of the water column. They were influenced by redox processes (types V and VI), enhanced catchment erosion (type II), or recent eutrophication (type I).

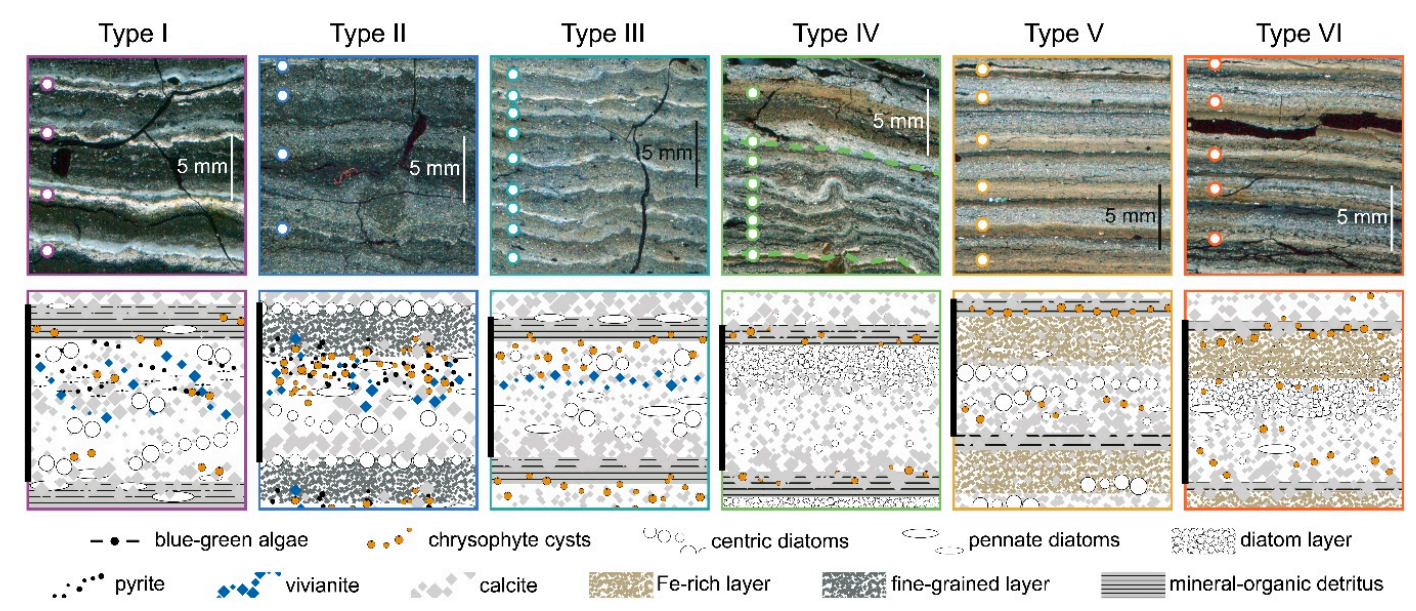

Figure 2. Top: Six varve microfacies (types I-VI) of Lake Żabińskie (thin sections scanned with polarized light). White dots mark the beginning of each varve year. Bottom: Conceptual varve models. Black bars indicate one year.

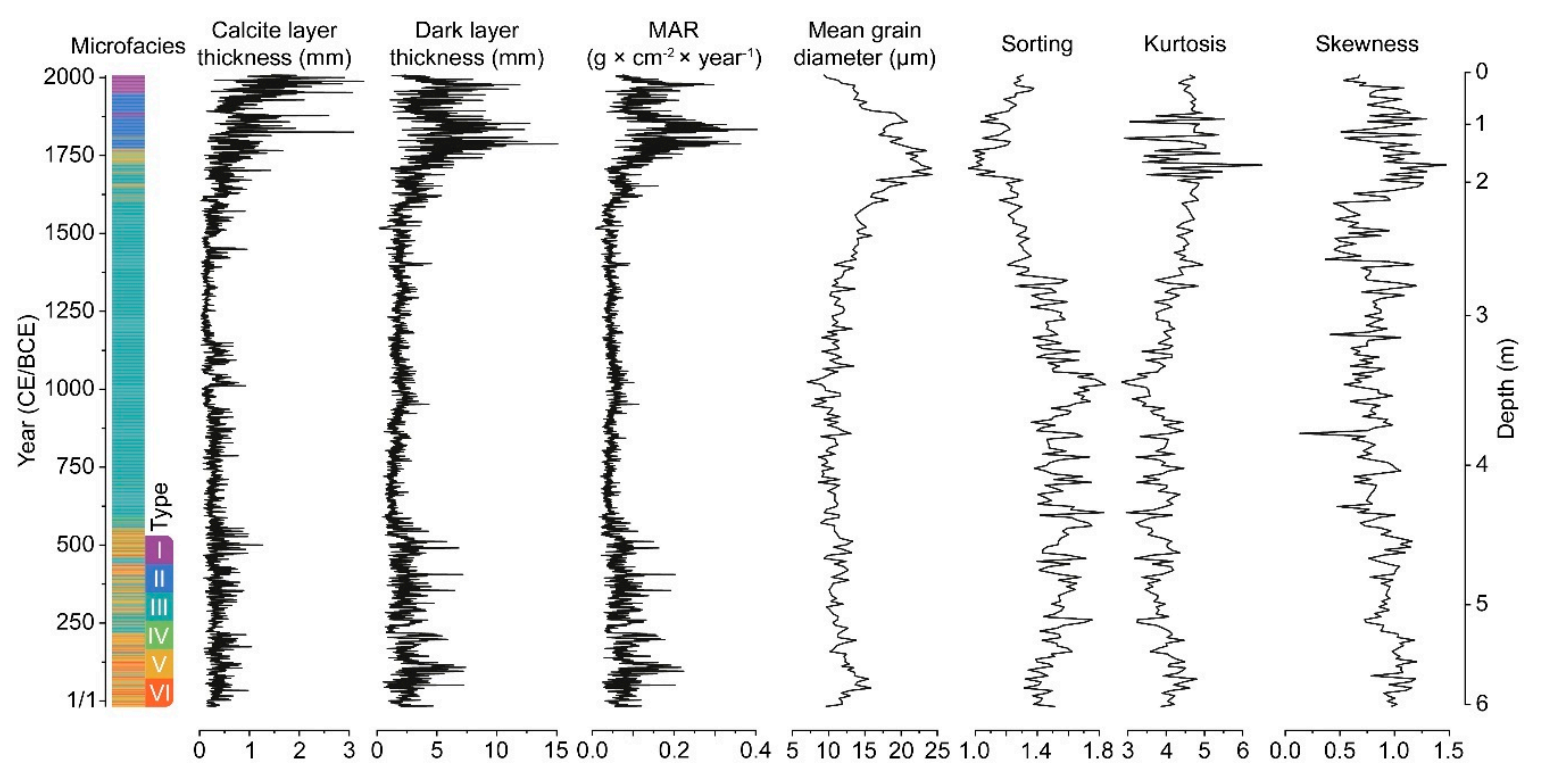

Figure 3. Varve microfacies with sedimentological, and grain-size variability plotted vs. time and depth.

Main patterns of sedimentological properties and grain-size indices are shown in Figure 3 with respective varve microfacies. Overall, both sedimentological characteristics and grain-size parameters 
are divided into four main phases. The first phase between ca. $17 \mathrm{BCE}$ and $520 \mathrm{CE}$ is characterized by elevated values and higher variability of all the variables except sediment sorting. From 520-1620 CE all values drop and remain relatively stable, with less sediment sorting. Between 1620 and $1870 \mathrm{CE}$ variables rise again, reaching respective maxima with very good sediment sorting. Finally, there is a decoupling between CT and DT, reflected also in mean grain-size with an overall drop toward the top.

After dataset reduction, the number of sediment samples corresponding to each varve type left seven samples of type I, 17 samples of type II, 126 samples of type III, 1 sample of type IV, 8 samples of type V, and 2 samples of type VI. For the needs of statistical analysis, types III and IV as well as V and VI were merged. The main sedimentological properties of the reduced dataset are illustrated by boxplots shown in Figure 4. The mean MAR exceeded $0.10 \mathrm{~g} \times \mathrm{cm}^{-2} \times$ year $^{-1}$ for most varve types with a maximum of $0.15 \pm 0.05 \mathrm{~g} \times \mathrm{cm}^{-2} \times$ year $^{-1}$ recorded for type II. The exceptions are types III $+\mathrm{IV}$, with a mean of $0.05 \pm 0.01 \mathrm{~g} \times \mathrm{cm}^{-2} \times$ year $^{-1}$. The lowest MAR of $0.03 \mathrm{~g}^{\circ} \mathrm{cm}^{-2} \times$ year $^{-1}$ is recorded within type III + IV, while the maximum value of $0.24 \mathrm{~g} \times \mathrm{cm}^{-2} \times$ year $^{-1}$ occurred in type II.

Calcite layer thickness varies between varve types, with highest values recorded for type I $(1.37 \pm 0.36 \mathrm{~mm})$. The other types were characterized by thinner calcite layers, with type III + IV reaching a minimum of $0.26 \pm 0.10 \mathrm{~mm}$ on average. Type III + IV also reaches the lowest value of $0.09 \mathrm{~mm}$, while a maximum of $1.84 \mathrm{~mm}$ is recorded within type I. Dark layer thickness shows a similar pattern with highest mean values reached for varve type II (5.43 $\pm 1.48 \mathrm{~mm})$, while the lowest value occurs for type III + IV $(1.88 \pm 0.51 \mathrm{~mm})$. Overall, varves of types I and II reach higher values for all variables, while type II exhibited the most dispersed properties. Varves of type III + IV are most uniform and generally at the lower end. Type V + VI shows values in between other types.

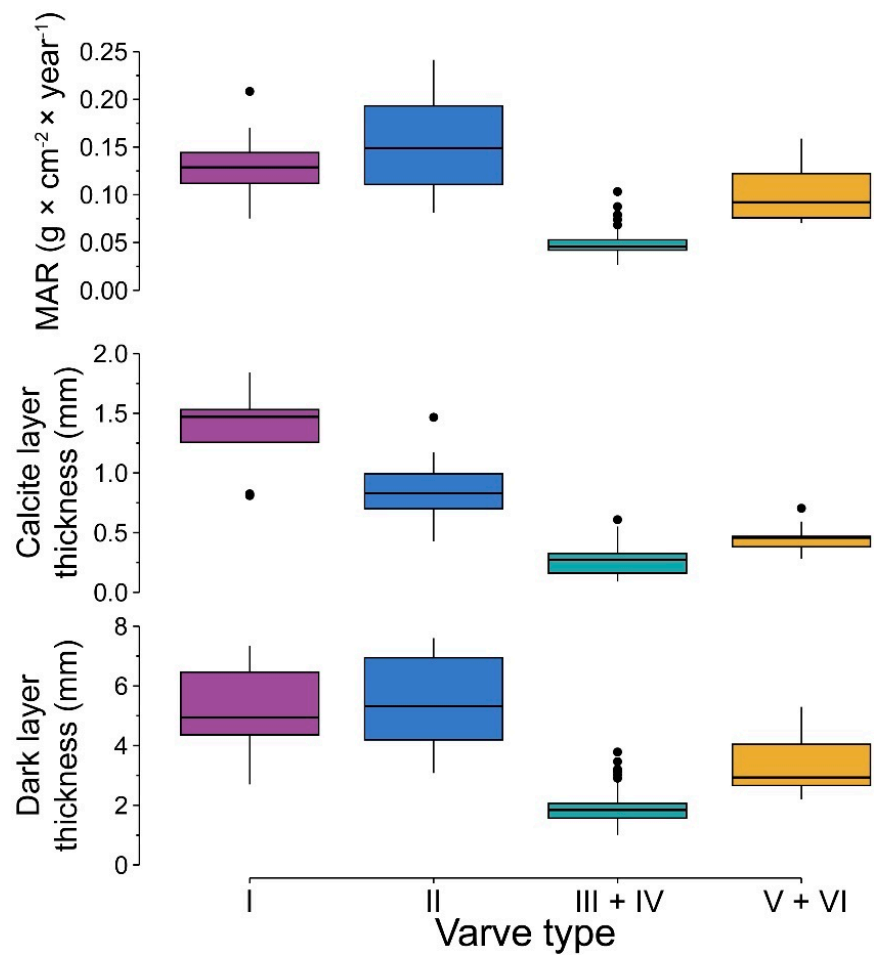

Figure 4. Boxplots of sedimentological properties aggregated for varve types I-VI. Boxplot hinges represent the 25th and 75th quantiles, solid horizontal line represents the mean, notches indicate maximum and minimum values within the 1.5 inter-quartile range and black dots represent outliers.

\subsection{Grain-Size}

Type II varves are dominated by relatively coarse material with a mean particle-size of 13.5-20.9 $\mu \mathrm{m}$. Lower mean particle-size is associated with type III + IV (7.1-24.3 $\mu \mathrm{m})$. Overall, types I, III + IV and V + VI are characterized by a minimum mean particle-size below $10 \mu \mathrm{m}$. On the 
other hand, the maximum mean particle-size exceeds $20.0 \mu \mathrm{m}$ within types II, III + IV, and V + VI. The median particle-size, together with the 10th $\left(\mathrm{P}_{10}\right)$ and 90th $\left(\mathrm{P}_{90}\right)$ percentiles show the margins of distributions and follow similar patterns like the mean particle-size (Figure 5a). The mean kurtosis ranges from 4.01 (type III + IV) to 4.66 (type II). Mean skewness is between 0.78 (type III + IV) and 1.07 (type V + VI), with type V + VI reaching overall higher values and low dispersions.
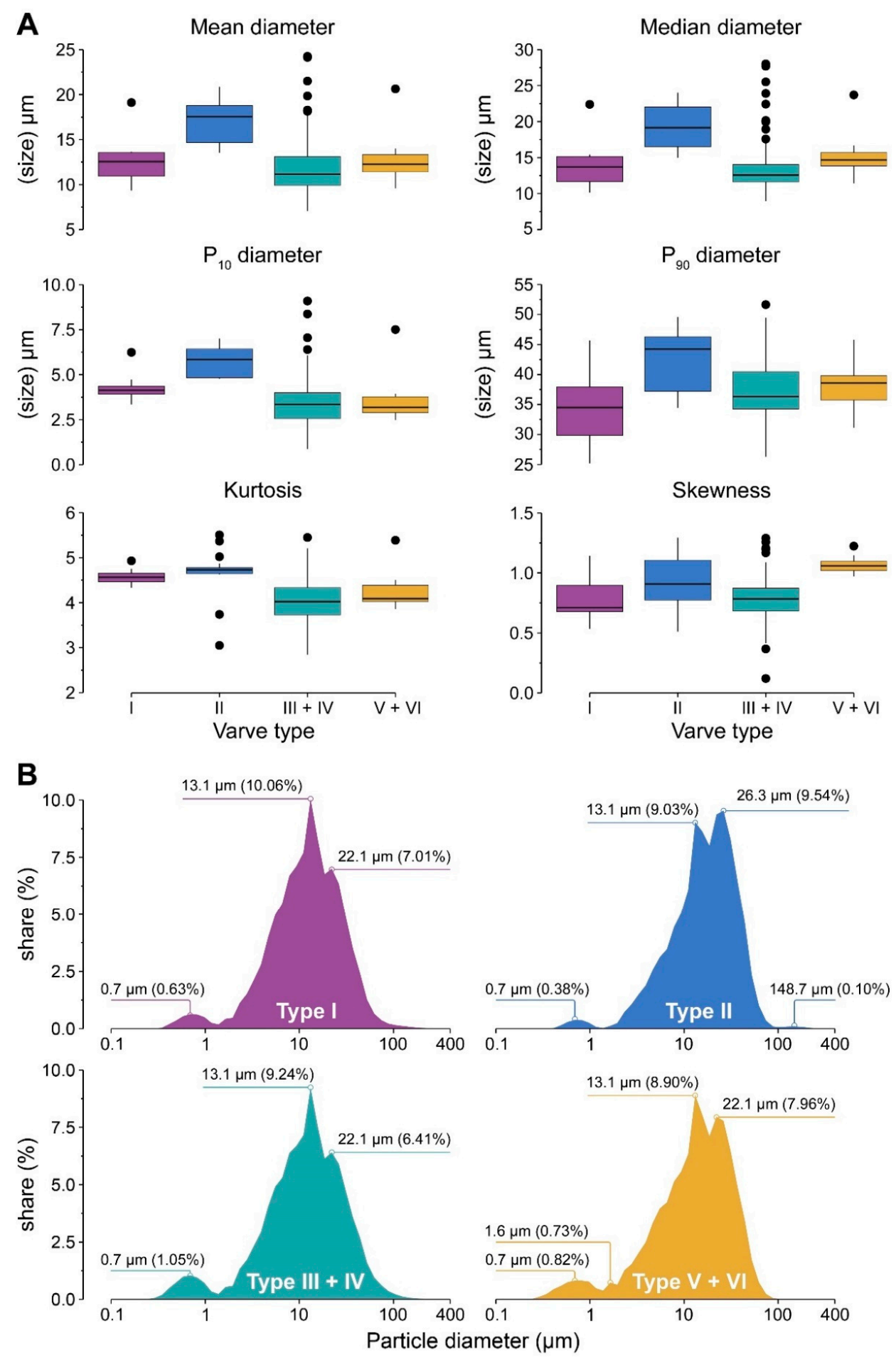

Figure 5. (a) Boxplots of main grain-size indices and parameters aggregated by varve type. (b) Average grain-size distribution aggregated by varve type (labels indicate positions of modes, respective size, and relative share). Boxplots features as in Figure 4. 
Averaged distributions of particle-size, aggregated by type (Figure $5 b$ ), show that varve types II and V + VI are in fact shifted towards coarser material relative to the other types. Type I shows a similar distribution like type III + IV. However, the secondary grain-size peak is smaller than $1 \mu \mathrm{m}$ and better pronounced for type III + IV than for type I. While all the distributions are shifted towards coarser grains, the secondary peak below $1 \mu \mathrm{m}$ is also well-pronounced. Grain-size distributions of all types are determined by a dominant silt fraction. Main shifts occur for coarser silt around $22.1 \mu \mathrm{m}$ (types I, III + IV, V + VI) or $26.3 \mu \mathrm{m}$ (type II), and finer silt around $13.1 \mu \mathrm{m}$ (all types). Mean grain-sizes calculated for average distributions range from $11.5 \mu \mathrm{m}$ (type III + IV) to $16.9 \mu \mathrm{m}$ (type II), with three to four modes (Figure $5 \mathrm{~b}$ ) appearing mostly at $22.1 \mu \mathrm{m}, 13.1 \mu \mathrm{m}$, and $0.7 \mu \mathrm{m}$. Characteristic for type II is an additional, coarse mode at $148.7 \mu \mathrm{m}$. The samples were mostly poorly $(\mathrm{n}=159)$ or moderately $(n=3)$ sorted, with either meso $(n=31)$ or leptokurtic $(n=131)$, fine $(n=159)$ skewed or symmetrical $(\mathrm{n}=3)$ distribution.

Overall, all varves belong either to medium silt (I and III + IV) or coarse silt (II and V + VI) grain-size classes. The relationships between different sediment classes are shown in Figure 6. Some degree of separation is visible between types, with type III + IV shifted slightly to the direction of clay and sand-sized particles, with a gradual change towards silt-dominated type II. The mean clay content varies between $1.7 \pm 0.8 \%$ (type II) and $6.3 \pm 3.3 \%$ (type III + IV). Silt dominates all samples with rather high differences between types. It is least abundant in type III + IV with a mean of $91.2 \pm 3.3 \%$, while for type II silt reaches $96.4 \pm 1.1 \%$. Sand-sized particles are most prominent in type III + IV $(2.4 \pm 1.2 \%)$.

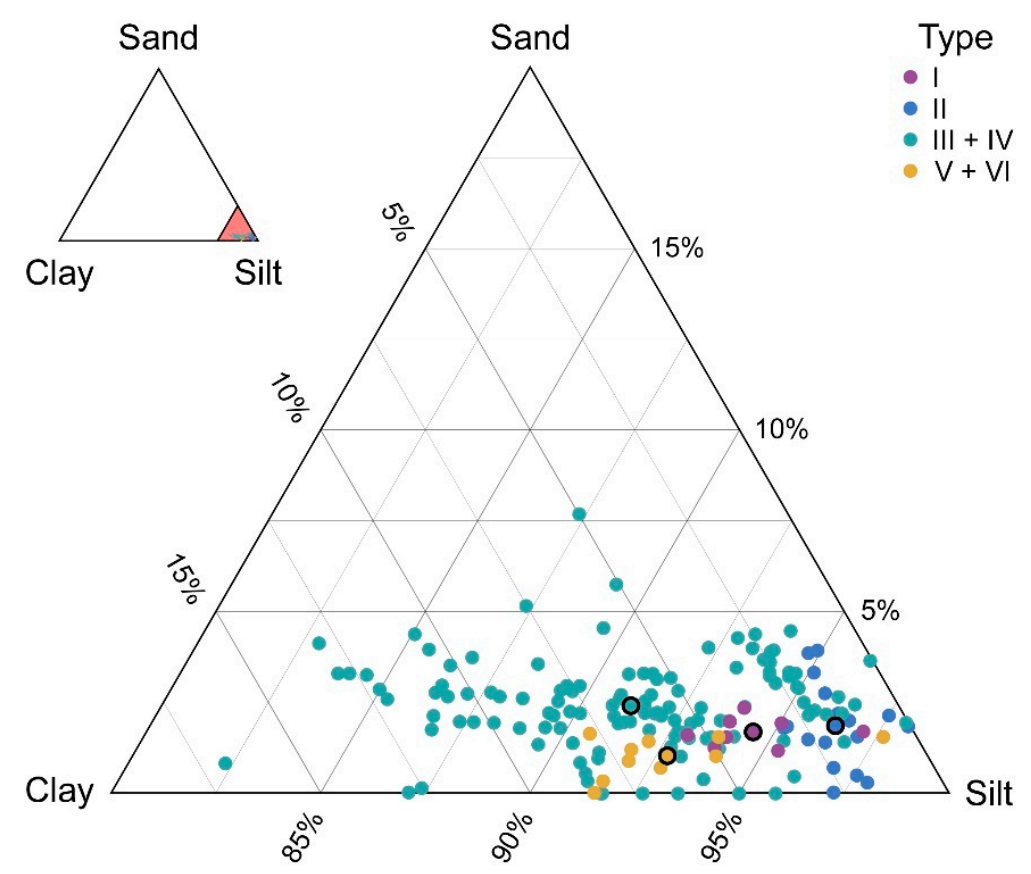

Figure 6. Ternary diagram of grain-size data. Larger points indicate values for mean grain-size distributions. The smaller triangle shows the location of samples within the full ternary diagram.

\subsection{Statistical Analyses}

\subsubsection{Principal Components Analysis}

Principal components analysis (PCA) was carried out on three main sedimentological variables (MAR, CT, DT) with the addition of parameters calculated from grain-size distributions (Figure 7). Four principal components exceeded 5\% of the total explained variance (PC1: 57.2\%; PC2: $16.4 \%$; PC3: 11.3\%; PC4: 8.6\%), while only PC1 passed the broken-stick test. There are three main groups of visible vectors: (1) sedimentological variables (CT, DT, MAR) and skewness, (2) variables describing 
distribution ( $\mathrm{P}_{10}, \mathrm{P}_{90}$, mean, and median diameter) with kurtosis, and (3) sorting. Samples tended to cluster to some extent: types I and II were mostly related to sedimentological variables while type III + IV had strong relationships with variables describing particle-size distributions (except skewness). Samples from type V + VI were more dispersed between other types.

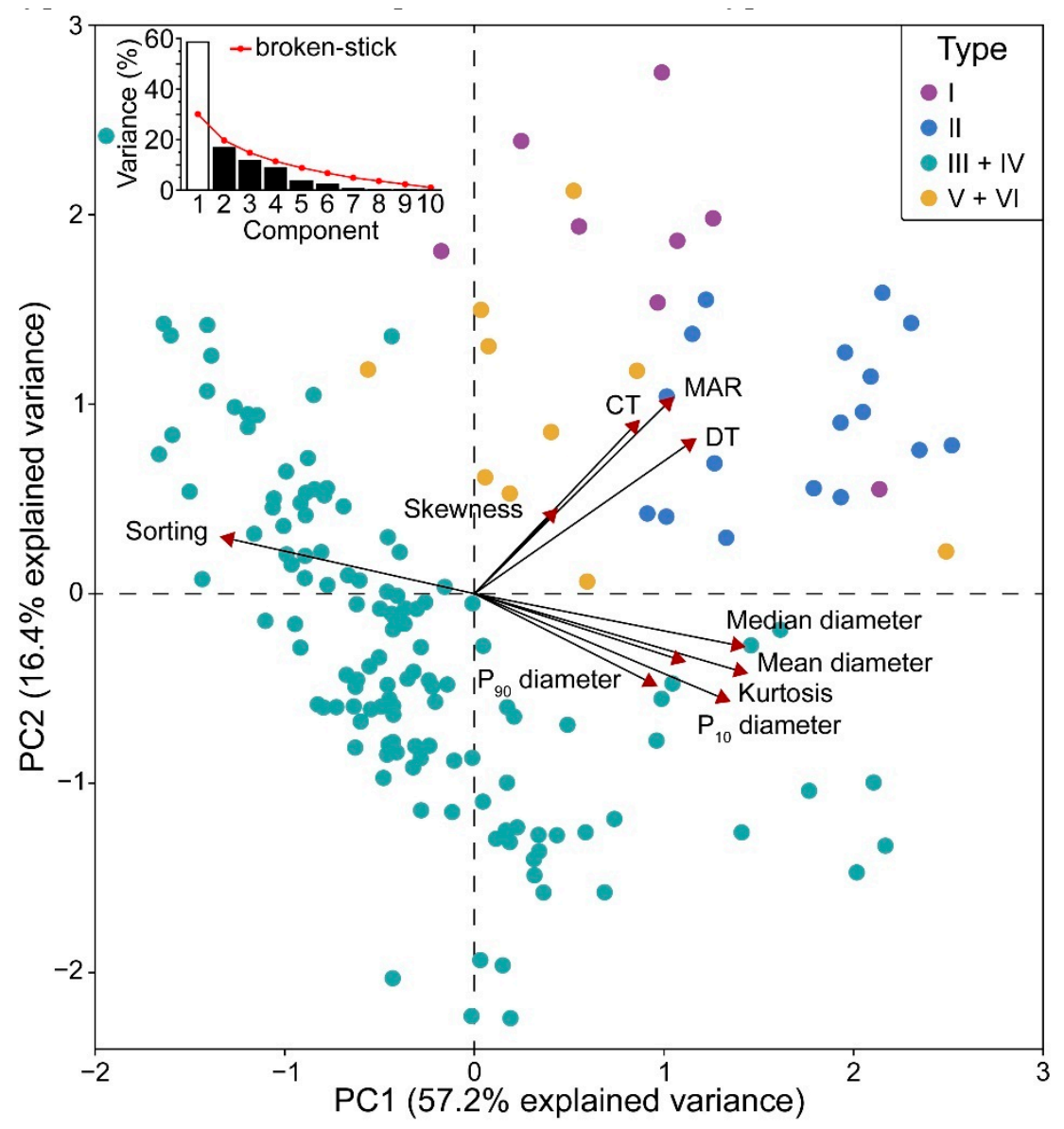

Figure 7. PCA biplot of sedimentological and grain-size data. CT—calcite layer thickness; DT—dark layer thickness; MAR—mass accumulation rate.

\subsubsection{End-Member Analysis}

End-member analysis resulted in recognition of five different end-members (EM) (Figure 8a). Coarsest end-members explain the smallest proportion of variation with only $5.4 \%$ and $5.0 \%$ for EM1 (mode at $44.0 \mu \mathrm{m}$ ) and EM2 (mode at $37.0 \mu \mathrm{m}$ ), respectively. The end-members associated with finer material $(7.8 \mu \mathrm{m}$ to $31.0 \mu \mathrm{m})$ explain over $25 \%$ of variance each. EM1 was mostly visible within type III + IV, with some observations occurring within type II and IV. EM2 was recorded only in type III + IV, rarely dominating this type. EM3 was highly variable among the types, with highest relative values recorded within type II and V + VI. Types I and III + IV reach overall low values, with some outliers in type III + IV. EM4 shows a gradual decrease starting from type I until type III + IV. A slight rise within type $\mathrm{V}+\mathrm{VI}$ is also visible. EM5 is virtually absent within type II and reaches the highest values within type III + IV. 
A
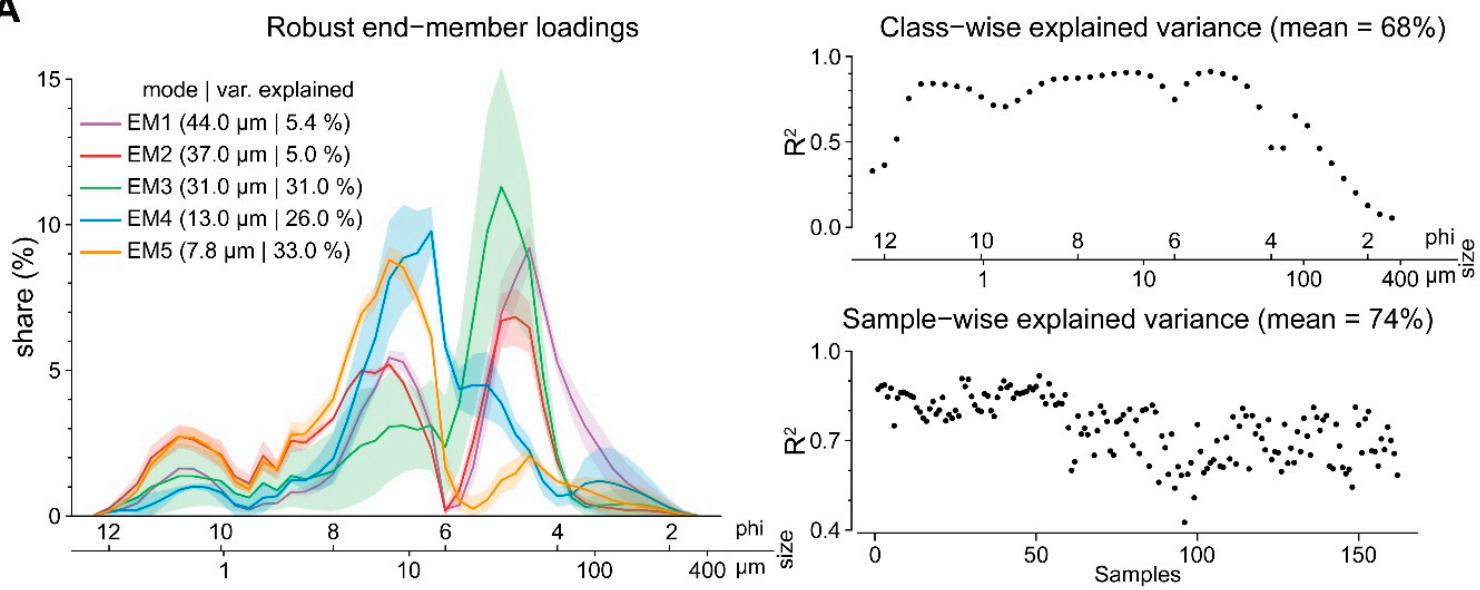

B
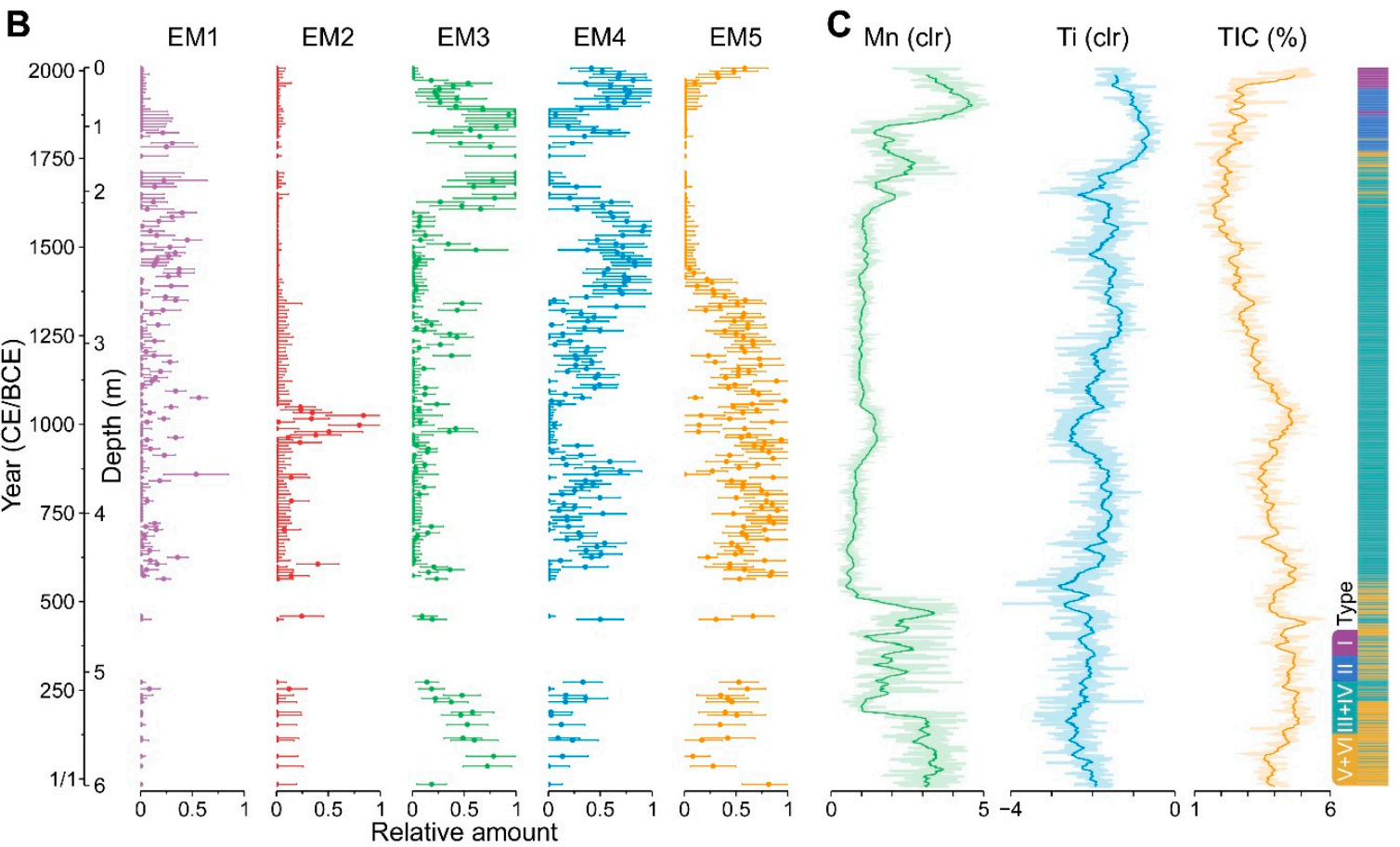

Figure 8. (a) End-members loadings with diagnostic plots. (b) Relative abundance of end-members vs time and depth. (c) Profiles of selected geochemical proxies ( $\mu$ XRF centered log-ratios (clr) of Mn and Ti, TIC-total inorganic carbon) with a 20-year running mean and varve types (Żarczyński et al., 2019; modified).

\section{Discussion}

Biogenic varves from Lake Żabińskie show macro- and microscopic differences, mostly resulting from variations of in-lake processes. Despite different structures, the texture of these sediments is generally similar and, as a result of their autochthonous origin, dominated by silt-sized particles. This can be related to calcite crystals as well as diatom frustules abundant in all sediment samples. Sediments of Lake Żabińskie are dominated by small (approx. 4 to $50 \mu \mathrm{m}$ ), planktonic diatom taxa (Aulacoseira, Stephanodiscus, Cyclotella). Larger (over $100 \mu \mathrm{m}$ ), benthic diatoms (Fragilaria, Pseudostaurosira, Staurosira) are scarce. Therefore, inferences about external transport processes and sources are limited due to minor contributions of allochthonous material associated with aeolian or fluvial provenance. Annually resolved sedimentological data, combined with the standard grain-size allows separation of Lake Żabińskie varve types. Differences based on mean, median, $\mathrm{P}_{10}$, and $\mathrm{P}_{90}$ particle-sizes show similar patterns. Type II varves consistently document the highest values, 
suggesting contributions linked to relatively coarser material showing elevated erosion rates [40]. On the other hand, the remaining varve types exhibit similar patterns, mostly due to deposition of autochthonous material. However, type III + IV varves have numerous outliers of coarser particle-size. This is probably due to episodic deposition of aggregated autochthonous material such as calcite [41].

In terms of statistical measures such as sorting, skewness and kurtosis, all varve types exhibit considerable similarity. Analyzed sediments are poorly sorted due to dominance of the silt fraction, which is deposited under lower flow conditions [42,43], which do not favor sorting processes. Transport and deposition of sediments in the lakes could be directly influenced by wind fetch and wind stress, effectively changing sedimentation patterns over time, potentially leading to complex sorting processes [44]. Furthermore, sediments of Lake Żabińskie are comprised of products of biogenic (diatoms) and biochemical (carbonates, Fe and Mn (hydr)oxides) processes, which are more important than transport and sorting. Selective sediment deposition is demonstrated by positive skewness associated with dominance of a fraction coarser than the median [45]. On the other hand, highest skewness values recorded within type II show a more diverse deposition setting due to the higher influence of allochthonous material. Grain-size distributions of varve types do not differ significantly, and fraction modes are similar, with minor changes of their relative shares (Figure $5 b$ ).

Additionally, PCA analysis of grain-size and sedimentological data from Lake Żabińskie results to some degree in separation of different varve types. The close relationship between CT, MAR and type I varves suggests thickness of the calcite layer as the controlling factor for the overall accumulation of the given year-a possible response to the increasing lacustrine productivity [46] and carbonate deposition [47]. On the other hand, type II varves are associated more with DT implying higher importance of accumulation of detrital components rather than poorly developed calcite layers. These varves developed in response to forest clearing in the catchment area. Mineral matter deposition was caused by soil erosion and increased delivery of allochthonous material [40], leading to a more prominent role of terrestrial matter in the varve structure. Additionally, at that time intensity of lake mixing increased, which caused poor varve preservation. Varve type III + IV is related to major grain-size characteristics, i.e., sorting or mean particle-size and kurtosis. This type is characteristic for an over 1000 year-long period of meromixis, when catchment was densely forested reducing wind stress on the lake [39]. Type V + VI shows no apparent tendencies, which are explained by the complicated structure and origin, where both sedimentation and chemical processes played important roles. Occurrence of this type is characteristic for periods of more intense lake mixing. This in turn caused deposition of Fe and Mn (hydr)oxides forming visible sublayers in varves. These varves co-occurred with early human impact on the lake catchment [39].

End-member analysis and distribution decomposition allows separation and recognition of the sources and transport processes of allochthonous material. As allochthonous input is of minor importance for Lake Żabińskie, we attempt to compare end-members with geochemical data (Figure 8c) [11,39]. This leads to the recognition and definition of non-clastic end-members. Significance of correlations is corrected for autocorrelation [48]. The pattern visible in EM3 resembles Mn variability of $\mu$ XRF data $(\mathrm{r}=0.46, p<0.05)$. With a mode around $31.0 \mu \mathrm{m}$, this indicates presence of cemented aggregates of mineral matter or carbonates coated with these (hydr)oxides. Mn and Fe variability in sediments of Lake Żabińskie during the last 2000 years was controlled mostly by changes in oxygenation of the water column [39]. Higher abundance in the type V + VI seems to support this interpretation. The high values noted also within type II varves are a sign of metal scavenging, adsorption onto silt-sized mineral particles and coating of grains [25]. Comparing EM4 with the Ti record $(r=0.35, p<0.05)$ suggests deposition of silt-sized (mode at $13.0 \mu \mathrm{m})$ allochthonous mineral matter. EM5 is probably associated with the abundance of calcite in the sediments showing a similar pattern like TIC [39] $(\mathrm{r}=0.67, p<0.05)$. Calcite is an important component for every type, except type II, where calcite laminas are poorly developed and of low quality [40]. EM1 and EM2 explain a relatively small portion of the total variance and complicate interpretations. Finally, superimposed peaks of end-member distributions might be caused by the authigenic nature of the sediments. Precipitation 
and redeposition processes could lead to a different size of accumulated material of the same origin. Furthermore, the end-member analysis should be treated with caution, especially when run without reference based on samples of known origin [49]. Analysis of different algorithms conducted by van Hateren et al. [50] suggests that EMMAgeo might be prone to the occurrence of artifacts in end-member grain-size distributions. Yet, comparison with geochemical data might act as external validation.

It should be stressed that there are multiple sources of uncertainty in our analysis. The first is related to the inhomogeneity of samples that contain more than one varve type. In this way, signals from two varve types are mixed, leading to a weak separation between grain-size characteristics of different varve types. Secondly, lacustrine sedimentation in low-land lakes of the temperate zone is dominated by in-lake production and biogeochemical processes rather than accumulation of minerogenic matter. Due to this, typical discrimination between transport regimes and particle deposition could not be applied. The finest material tends to aggregate when settling down the water column, which is important for metal compounds and (hydr)oxides or carbonates [51]. Additionally, even though not studied here, diatoms further influence grain-size determination. Diatom frustules often are abundant and come in a variety of shapes and sizes. These factors influence the interpretation when the range of particle-size is narrow and covers more than purely allochthonous matter.

Our results suggest that even bulk data of lower, non-annual resolution is useful for discrimination between varve types. Comparison of structure and aggregated grain-size analyses improves and validates previously determined varve microfacies. A step forward will be varve-by-varve sampling, sequential extraction of sediment components and repeated grain-size measurements. If applied, this might lead to recognition of particle-sizes associated with different components. Furthermore, it would be helpful in assessing the relation between particle-size and their scavenging potential $[52,53]$.

\section{Conclusions}

We compared bulk grain-sized data with an annually resolved record of varve properties and microfacies and found that even with aggregated data it is possible to partially discriminate varve microfacies. End-member analysis resulted in the attribution of end-members to specific sedimentation styles (i.e., precipitation of carbonates, formation of metal (hydr)oxides, and deposition of clastic particles), as well as tracing relative changes of their respective abundance over time. Therefore, we conclude that grain-size analysis is useful for more than characterization of the mineral component of biogenic lake sediments. Further studies with sequential extraction and separation of individual sediment components will likely improve the interpretation of end-member analysis.

Supplementary Materials: The following are available online at http://www.mdpi.com/2571-550X/2/1/8/s1.

Author Contributions: Conceptualization: M.Ż. and W.T.; methodology: M.Ż., W.T., and J.S.; investigation: M.Ż.; writing—original draft preparation: M.Ż. and W.T.; writing—review and editing: M.Ż., W.T., and J.S.; visualization: M.Ż.; project administration: W.T.; funding acquisition: W.T. and M.Ż.

Funding: This research was funded by National Science Centre, grant number 2014/13/B/ST10/01311. Additionally, MZ was funded by University of Gdansk, grant number 538-G110-B576-16.

Acknowledgments: We would like to sincerely thank Anna Poraj-Górska, Dorota Chmielowska, Michał Marosz, and Benjamin Amann for their help and contribution. We also thank three anonymous reviewers for their comments which substantially improved this manuscript.

Conflicts of Interest: The authors declare no conflict of interest.

\section{References}

1. Brauer, A. Annually Laminated Lake Sediments and Their Palaeoclimatic Relevance. In The Climate in Historical Times: Towards a Synthesis of Holocene Proxy Data and Climate Models; Fischer, H., Kumke, T., Lohmann, G., Flöser, G., Miller, H., von Storch, H., Negendank, J.F.W., Eds.; Springer: Berlin/Heidelberg, Germany, 2004; Volume 18, pp. 109-127, ISBN 978-3-662-10313-5. 
2. Zolitschka, B.; Francus, P.; Ojala, A.E.K.; Schimmelmann, A. Varves in lake sediments-A review. Quat. Sci. Rev. 2015, 117, 1-41. [CrossRef]

3. Ojala, A.E.K.; Francus, P.; Zolitschka, B.; Besonen, M.; Lamoureux, S.F. Characteristics of sedimentary varve chronologies-A review. Quat. Sci. Rev. 2012, 43, 45-60. [CrossRef]

4. Bonk, A.; Tylmann, W.; Amann, B.; Enters, D.; Grosjean, M. Modern limnology, sediment accumulation and varve formation processes in Lake Żabińskie, northeastern Poland: Comprehensive process studies as a key to understand the sediment record. J. Limnol. 2015, 74, 358-370. [CrossRef]

5. Zolitschka, B. Varved lake sediments. In Encyclopedia of Quaternary Science; Elsevier B.V.: Amsterdam, The Netherlands, 2007; pp. 3105-3114, ISBN 978-0-444-52747-9.

6. Dräger, N.; Theuerkauf, M.; Szeroczyńska, K.; Wulf, S.; Tjallingii, R.; Plessen, B.; Kienel, U.; Brauer, A. Varve microfacies and varve preservation record of climate change and human impact for the last 6000 years at Lake Tiefer See (NE Germany). Holocene 2017, 27, 450-464. [CrossRef]

7. Trapote, M.C.; Vegas-Vilarrúbia, T.; López, P.; Puche, E.; Gomà, J.; Buchaca, T.; Cañellas-Boltà, N.; Safont, E.; Corella, J.P.; Rull, V. Modern sedimentary analogues and integrated monitoring to understand varve formation in the Mediterranean Lake Montcortès (Central Pyrenees, Spain). Palaeogeogr. Palaeoclimatol. Palaeoecol. 2018, 496, 292-304. [CrossRef]

8. Last, W.M.; Smol, J.P. An Introduction to Physical and Geochemicalmethods Used in Paleolimnology. In Tracking Environmental Change Using Lake Sediments. Volume 2: Physical and Geochemical Methods; Last, W.M., Smol, J.P., Eds.; Kluwer Academic Publishers: Dordrecht, The Netherlands, 2001; Volume 2, pp. 1-5, ISBN 978-0-306-47670-9.

9. Smol, J.P.; Birks, J.; Last, W.M. Using biology to study long-term environmental change. In Tracking Environmental Change Using Lake Sediments. Volume 3: Terrestrial, Algal, and Siliceous Indicators; Smol, J.P., Birks, H.J.B., Last, W.M., Eds.; Kluwer Academic Publishers: Dordrecht, The Netherlands, 2001; Volume 3, p. 3.

10. Smol, J.P.; Birks, H.J.B.; Last, W.M. Zoological indicators in lake sediments: An introduction. In Tracking Environmental Change Using Lake Sediments. Volume 4: Zoological Indicators; Smol, J.P., Birks, H.J.B., Last, W.M., Eds.; Kluwer Academic Publishers: Dordrecht, The Netherlands, 2001; Volume 4, pp. 1-4.

11. Hernández-Almeida, I.; Grosjean, M.; Gomez-Navarro, J.J.; Larocque-Tobler, I.; Bonk, A.; Enters, D.; Ustrzycka, A.; Piotrowska, N.; Przybylak, R.; Wacnik, A.; et al. Resilience, rapid transitions and regime shifts: Fingerprinting the responses of Lake Zabinskie (NE Poland) to climate variability and human disturbance since AD 1000. Holocene 2017, 27, 258-270. [CrossRef]

12. Last, W.M. Textural Analysis of Lake Sediments. In Tracking Environmental Change Using Lake Sediments. Volume 2: Physical and Geochemical Methods; Last, W.M., Smol, J.P., Eds.; Kluwer Academic Publishers: Dordrecht, The Netherlands, 2001; Volume 2, pp. 41-81, ISBN 978-0-306-47670-9.

13. Jin, Z.; Li, F.; Cao, J.; Wang, S.; Yu, J. Geochemistry of Daihai Lake sediments, Inner Mongolia, north China: Implications for provenance, sedimentary sorting, and catchment weathering. Geomorphology 2006, 80, 147-163. [CrossRef]

14. IJmker, J.; Stauch, G.; Dietze, E.; Hartmann, K.; Diekmann, B.; Lockot, G.; Opitz, S.; Wünnemann, B.; Lehmkuhl, F. Characterisation of transport processes and sedimentary deposits by statistical end-member mixing analysis of terrestrial sediments in the Donggi Cona lake catchment, NE Tibetan Plateau. Sediment. Geol. 2012, 281, 166-179. [CrossRef]

15. Schillereff, D.N.; Chiverrell, R.C.; Macdonald, N.; Hooke, J.M. Flood stratigraphies in lake sediments: A review. Earth-Sci. Rev. 2014, 135, 17-37. [CrossRef]

16. Ota, Y.; Kawahata, H.; Sato, T.; Seto, K. Flooding history of Lake Nakaumi, western Japan, inferred from sediment records spanning the past 700 years. J. Quat. Sci. 2017, 32, 1063-1074. [CrossRef]

17. Liu, X.; Vandenberghe, J.; An, Z.; Li, Y.; Jin, Z.; Dong, J.; Sun, Y. Grain size of Lake Qinghai sediments: Implications for riverine input and Holocene monsoon variability. Palaeogeogr. Palaeoclimatol. Palaeoecol. 2016, 449, 41-51. [CrossRef]

18. Zhai, Q.; Guo, Z.; Li, Y.; Li, R. Annually laminated lake sediments and environmental changes in Bashang Plateau, North China. Palaeogeogr. Palaeoclimatol. Palaeoecol. 2006, 241, 95-102. [CrossRef]

19. De Geer, G. On late Quaternary time and climate. Geol. Foereningan i Stock. Foerhandlingar 1908, 30, $459-464$. [CrossRef] 
20. Ojala, A.E.K.; Kosonen, E.; Weckström, J.; Korkonen, S.; Korhola, A. Seasonal formation of clastic-biogenic varves: The potential for palaeoenvironmental interpretations. GFF 2013, 135, 237-247. [CrossRef]

21. Haltia-Hovi, E.; Saarinen, T.; Kukkonen, M. A 2000-year record of solar forcing on varved lake sediment in eastern Finland. Quat. Sci. Rev. 2007, 26, 678-689. [CrossRef]

22. Amann, B.; Lamoureux, S.F.; Boreux, M.P. Winter temperature conditions (1670-2010) reconstructed from varved sediments, western Canadian High Arctic. Quat. Sci. Rev. 2017, 172, 1-14. [CrossRef]

23. Ojala, A.E.K.; Francus, P. Comparing X-ray densitometry and BSE-image analysis of thin section in varved sediments. Boreas 2002, 31, 57-64. [CrossRef]

24. Ojala, A.E.K. Application of X-ray radiography and densitometry in varve analysis. In Image Analysis, Sediments and Paleoenvironments; Francus, P., Ed.; Springer: Dordrecht, The Netherlands, 2004; pp. 187-202.

25. Gee, G.W.; Or, D. Particle-Size Analysis. In Methods of Soil Analysis: Part 4 Physical Methods; SSSA Book Ser. 5.4; Soil Science Society of America: Madison, WI, USA, 2002; pp. 255-293, ISBN 978-0-89118-893-3.

26. Augustinus, P.; Bleakley, N.; Deng, Y.; Shane, P.; Cochran, U. Rapid change in early Holocene environments inferred from Lake Pupuke, Auckland City, New Zealand. J. Quat. Sci. 2008, 23, 435-447. [CrossRef]

27. Solon, J.; Borzyszkowski, J.; Bidłasik, M.; Richling, A.; Badora, K.; Balon, J.; Brzezińska-Wójcik, T.; Chabudziński, Ł.; Dobrowolski, R.; Grzegorczyk, I.; et al. Physico-geographical mesoregions of Poland: Verification and adjustment of boundaries on the basis of contemporary spatial data. Geogr. Pol. 2018, 91, 143-170. [CrossRef]

28. Marks, L.; Dzierżek, J.; Janiszewski, R.; Kaczorowski, J.; Lindner, L.; Majecka, A.; Makos, M.; Szymanek, M.; Tołoczko-Pasek, A.; Woronko, B. Quaternary stratigraphy and palaeogeography of Poland. Acta Geol. Pol. 2016, 66, 403-427. [CrossRef]

29. Szumański, A. Objaśnienia do Szczegółowej Mapy Geologicznej Polski, Arkusz Giżycko (104) (Explanation to the Detailed Geological Map of Poland, Sheet Giżycko (104)); Państwowy Instytut Geologiczny: Warszawa, Poland, 2000.

30. Pochocka-Szwarc, K.; Lisicki, S. Objaśnienia do Szczegółowej Mapy Geologicznej Polski, Arkusz Orłowo (105) (Explanation to the Detailed Geological Map of Poland, Sheet Orłowo (105)); Państwowy Instytut Geologiczny_Państwowy Instytut Badawczy: Warszawa, Poland, 2015; ISBN 9788378634331.

31. Bonk, A.; Tylmann, W.; Goslar, T.; Wacnik, A.; Grosjean, M. Comparing Varve Counting And 14C-Ams Chronologies In The Sediments Of Lake Żabińskie, Northeastern Poland: Implications For Accurate 14C Dating Of Lake Sediments. Geochronometria 2015, 42, 159-171. [CrossRef]

32. Żarczyński, M.; Tylmann, W.; Goslar, T. Multiple varve chronologies for the last 2000 years from the sediments of Lake Żabińskie (northeastern Poland)—Comparison of strategies for varve counting and uncertainty estimations. Quat. Geochronol. 2018, 47, 107-119. [CrossRef]

33. Tylmann, W.; Bonk, A.; Goslar, T.; Wulf, S.; Grosjean, M. Calibrating 210Pb dating results with varve chronology and independent chronostratigraphic markers: Problems and implications. Quat. Geochronol. 2016, 32, 1-10. [CrossRef]

34. Blott, S.J.; Pye, K. GRADISTAT: A grain size distribution and statistics package for the analysis of unconsolidated sediments. Earth Surf. Process. Landf. 2001, 1248, 1237-1248. [CrossRef]

35. Hamilton, N. ggtern: An Extension to "ggplot2", for the Creation of Ternary Diagrams 2018. Available online: https:/ / cran.r-project.org/package=ggtern (accessed on 1 November 2018).

36. R Core Team. R: A Language and Environment for Statistical Computing; R Core Team: Vienna, Austria, 2018.

37. Dietze, E.; Maussion, F.; Ahlborn, M.; Diekmann, B.; Hartmann, K.; Henkel, K.; Kasper, T.; Lockot, G.; Opitz, S.; Haberzettl, T. Sediment transport processes across the Tibetan Plateau inferred from robust grain-size end members in lake sediments. Clim. Past 2014, 10, 91-106. [CrossRef]

38. Dietze, M.; Dietze, E. EMMAgeo: End-Member Modelling of Grain-Size Data 2016. Available online: https:/ / github.com/coffeemuggler/EMMAgeo (accessed on 1 November 2018).

39. Żarczyński, M.; Wacnik, A.; Tylmann, W. Tracing lake mixing and oxygenation regime using the Fe/Mn ratio in varved sediments: 2000 year-long record of human-induced changes from Lake Żabińskie (NE Poland). Sci. Total Environ. 2019, 657, 585-596. [CrossRef] [PubMed]

40. Bonk, A.; Kinder, M.; Enters, D.; Grosjean, M.; Meyer-Jacob, C.; Tylmann, W. Sedimentological and geochemical responses of Lake Żabińskie (north-eastern Poland) to erosion changes during the last millennium. J. Paleolimnol. 2016, 56, 239-252. [CrossRef] 
41. Czymzik, M.; Dulski, P.; Plessen, B.; Von Grafenstein, U.; Naumann, R.; Brauer, A. A 450 year record of spring-summer flood layers in annually laminated sediments from Lake Ammersee (southern Germany). Water Resour. Res. 2010, 46, 1-16. [CrossRef]

42. Sly, P.G.; Thomas, R.L.; Pelletier, B.R. Interpretation of moment measures derived from water-lain sediments. Sedimentology 1983, 30, 219-233. [CrossRef]

43. Szmańda, J.B. Main determinants of the grain size distribution of overbank deposits in Poland-An overview of literature on models of sedimentation. Geol. Q. 2018, 62, 873-880. [CrossRef]

44. Håkanson, L. The influence of wind, fetch, and water depth on the distribution of sediments in Lake Vänern, Sweden. Can. J. Earth Sci. 1977, 14, 397-412. [CrossRef]

45. McLaren, P. An Interpretation of Trends in Grain Size Measures. J. Sediment. Res. 1981, 51, 629-714. [CrossRef]

46. Amann, B.; Lobsiger, S.; Tylmann, W.; Filipiak, J.; Grosjean, M. Spring temperature variability and eutrophication history inferred from sedimentary pigments in the varved sediments of Lake Zabinskie, northeast Poland, 1907-2008 AD. Glob. Planet. Chang. 2014, 123, 86-96. [CrossRef]

47. Dean, W.E.; Megard, R.O. Environment of deposition of CaCO3 in Elk Lake, Minnesota. In Elk Lake, Minnesota: Evidence for Rapid Climate Change in the North-Central United States; Bradbury, J.P., Dean, W.E., Eds.; Geological Society of America: Boulder, CO, USA, 1993; pp. 97-114.

48. Bayley, G.V.; Hammersley, J.M. The "Effective" Number of Independent Observations in an Autocorrelated Time Series. Suppl. J. R. Stat. Soc. 1946, 8, 184. [CrossRef]

49. Weltje, G.J.; Prins, M.A. Muddled or mixed? Inferring palaeoclimate from size distributions of deep-sea clastics. Sediment. Geol. 2003, 162, 39-62. [CrossRef]

50. van Hateren, J.A.; Prins, M.A.; van Balen, R.T. On the genetically meaningful decomposition of grain-size distributions: A comparison of different end-member modelling algorithms. Sediment. Geol. 2018, 375, 49-71. [CrossRef]

51. Leng, M.J.; Jones, M.D.; Frogley, M.R.; Eastwood, W.J.; Kendrick, C.P.; Roberts, C.N. Detrital carbonate influences on bulk oxygen and carbon isotope composition of lacustrine sediments from the Mediterranean. Glob. Planet. Chang. 2010, 71, 175-182. [CrossRef]

52. Filipek, L.H.; Owen, R.M. Geochemical associations and grain-size partitioning of heavy metals in lacustrine sediments. Chem. Geol. 1979, 26, 105-117. [CrossRef]

53. Horowitz, A.J.; Elrick, K.A. The relation of stream sediment surface area, grain size and composition to trace element chemistry. Appl. Geochem. 1987, 2, 437-451. [CrossRef] 